\title{
The Moral Reasoning Of Sports Management Students In The United States And Italy
}

Almerinda Forte, Ph.D., St. John's University, USA

\begin{abstract}
The researcher analyzed the moral reasoning ability of Sports Management students in the United States and Italy. The researcher statistically analyzed data collected through a survey questionnaire designed to measure moral reasoning. The Defining Issues Test (DIT) developed by James Rest using Kohlberg's six stages of moral judgment was used in this study. The short form of the DIT was used. This form contains three ethical scenarios each accompanied by a set of questions. A statistical analysis package is used to interpret the data, with significance established at the .05 level. The U.S. students also received a demographic questionnaire. The Italian professor failed to distribute the demographic questionnaire to the students. The researcher in this study investigated the relationship between Italian Sports Management students' moral reasoning and United States Sports Management students' moral reasoning. The study also examined the relationship between gender and moral reasoning of Sports Management students in the United States. The principled moral reasoning (P-scores) of United States Sports Management lower and upper classmen was also examined. The researcher investigated the relationship between the United States Sports Management students' $P$ - scores and their religious affiliations, specifically Catholicism versus other affiliations. A sample of 41 undergraduate Sports Management students from a private Catholic university in New York City and 31 undergraduate Sports Management students from the University of Rome's Sports Management Program was utilized in this study. The mean " $P$ "- score (principled moral reasoning) was 22.3 for the United States Sports Management students with a standard deviation of 12.4. The mean "P"- score was 26.4 for the Italian Sports Management students with a standard deviation of 12.5. No statistically significant difference was found between Italian and American Sports Management students at the 0.05 level. The American female respondents reported higher mean " $P$ "- scores of 23.5 with a standard deviation of 10.2, than the American male respondents, who had a mean "P"- score of 21.7 and a standard deviation of 13.6. The American female Sports Management students had mean P-scores which were slightly higher than males but not significantly so. No statistically significant differences were found between the moral reasoning of American lower classmen and upper classmen in this study. No statistically significant differences were found between the moral reasoning of Catholic and non-Catholic Sports Management students.
\end{abstract}

Keywords: Moral Reasoning; Ethics and Students Moral Reasoning

\section{INTRODUCTION}

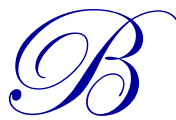

usiness communities and educational institutions have grown increasingly concerned about ethics over the last few decades, especially after Enron and World.com. Implementation of the Sarbanes-Oxley Act of 2002 evidenced this. This act provides legal protection for employees who report corporate misconduct. In 1991, the U.S. established Commission Guidelines for Organizations in order to facilitate and maintain ethical activities in companies. Technological advancements and the expansion of our service -oriented economy have drawn attention to corporate ethical responsibilities. The general framework for European corporate 
social responsibility (CSR) behavior and strategies consists of the Green Paper presented by the European Commission in July 2001. The purpose of this study was to determine the degree to which there are differences in moral reasoning between Italian Sports Management students and United States Sports Management students, and whether there are significant differences between gender and moral reasoning of Sports Management students in the United States. The study also investigates differences between the moral reasoning of American lower classmen and American upper classmen. This study also examines differences between the moral reasoning of American Catholic and American non-Catholic Sports Management students.

This study's necessity stems from its ability to provide insight in two areas. First, it measures how countries with different cultures and customs affect moral reasoning in college students. Second, it considers how technology and economic globalization affect the moral reasoning of our future leaders, today's college students.

The researcher statistically analyzed data collected through a survey questionnaire designed to measure ethical orientation (i.e. moral perspective). The United States students also received a demographic questionnaire. The Italian students did not receive a demographic questionnaire. The Italian professor failed to distribute the demographic questionnaire to the students. Therefore, the researcher could not compare the demographic data with that of the United States students.

The present study concludes that there were differences in the moral reasoning, but such differences were not statistically significant. The difference found between American and Italian students' responses might fall within the ranges of error, and merit further study.

\section{REVIEW OF THE LITERATURE}

Snodgrass's (1993) study found a significant difference in principled moral reasoning between lower and upper division status students. No significant difference at the .05 level was found between business and nonbusiness majors. Non-business majors' mean "P"-score (Principle Score) for upper division was slightly higher than that of upper business majors. Upper division business majors' mean "P"-score was 2.6 points below the mean of upper division non-business majors. Age groups had no significant differences in moral reasoning in Snodgrass's study. Females' "P"-scores were higher than males' scores in all groups. Snodgrass recommended additional and continued emphasis on ethics education for business students.

Unlike Snodgrass, the researcher in this study did not find a statistically significant difference in moral reasoning between American lower and upper classmen.

Fernandes' (1995) study investigated how an individual's level of moral reasoning interacts with perceptions of inequity and procedural explanations to influence affective responses. Fernandes' theoretical framework was based on Adams' $(1963,1965)$ theory of inequity and incorporated Leventhal's (1976a) theory of procedural justice and Kohlberg's (1969) theory of cognitive moral development. A scenario was used to determine perceptions of inequity and procedural justice. The participants were led to believe that they were either underrewarded or over-rewarded in comparison to their colleagues participating in the research. The research consisted of 127 men and 74 women. These men and women were enrolled in management, hotel and restaurant introductory business courses.

Fernandes' study found that perceptions of disadvantageous inequity, advantageous inequity and procedural injustice cause individuals to report negative effects. Moral maturity did not bear a significant influence on their emotional responses to perceived inequity and knowledge of the procedures used to determine the distribution outcome in the research. The DIT was used in this research to determine moral reasoning. Thirty percent of the participants were characterized as having high moral reasoning. Most of the participants were approximately 21 years old and juniors. It is highly unlikely that 21 year old juniors can be justifiably credited with a high level of moral reasoning according to the research. She believes that these students may have been familiar with the scenarios presented in the DIT and sought the right answer or approval with their responses. 
Unlike Fernandes' study, the researchers in this study did not find a statistically significant difference between Italian and American Sports Management students at the 0.05 level. The Italian Sports Management students' "P"-scores are slightly higher than the Americans' scores, but not significantly so.

James R. Rest and Darcia Narvaez edited "Moral Development in the Professions," which documents the studies that utilized the Defining Issues Test (DIT). Armstrong $(1984,1987)$ and all the studies discussed below can be found in the "Moral Development in the Professions." Armstrong used the Defining Issues Test (DIT) to examine accountants' ethical reasoning and moral development. The study consisted of a sample of Certified Public Accountants (CPA'S) and accounting students in Southern California. The mail survey method was used. The researcher found that Certified Public Accountants (CPA'S) and accounting students tended to be at lower levels of ethical reasoning than comparable groups of college-educated adults or college-aged students. Armstrong examined and compared Rest's (1979a) published work to her research. Armstrong speculates that accounting education may inhibit development to higher stages of ethical reasoning.

The researcher in this study found similar results to Armstrong. The mean "P"- score was 22.3 for the United States Sports Management students with a standard deviation of 12.4. The mean "P"- score was 26.4 for the Italian Sports Management students with a standard deviation of 12.4. Notably, this score falls below the "P"- score of 40 that Rest (1979) records as the average adult score.

Shaub $(1989,1994)$ measured the ethical sensitivity of Certified Public Accountant (CPA) practitioners at all position levels. Several offices of a Big-Six accounting firm located in the Midwest served as research participants. (The term "Big Six" refers to the largest U. S. public accounting firms, though we are presently down to four such firms.) The researcher related these ethical sensitivity measures to DIT "P"-score results. The Certified Public Accountants' (CPA'S') DIT "P"-scores decreased in the manager and partner ranks. The study also found significant differences between men's and women's DIT "P"-scores. Female accounting students and female Certified Public Accountants (CPA'S) tended to have higher DIT "P"-scores than their male counterparts. A significant association between self-reported GPA and DIT "P"-scores for both accounting students and practitioners was also found by the researcher. The notion that ethical reasoning is linked to other intellectual capacities as well as school achievement is in accordance with this finding.

Shaub and the researcher of this study found similar results. The American female respondents reported higher mean "P"-scores of 23.5 with a standard deviation of 10.2 than the American male respondents, who had a mean "P"-score of 21.7 and a standard deviation of 13.6. The United States female Sports Management students had mean "P"-scores which were slightly higher than males, but not significantly so.

Lampe and Finn (1992) researched accounting and Certified Public Accountants (CPA'S) in public firms. The research excluded partners. The researcher compared subjects' DIT results to responses on a questionnaire containing seven short ethical scenarios.

The research found that both accounting students and practitioners tend to have lower DIT "P"-scores than college-aged students, college-educated adults, and other professional groups such as those related to law and medicine. Lampe and Finn also found that the DIT stages measures better predicted ethical choice than did "P"scores. The DIT "P"-scores were relatively low for most subjects in the study. However, their percentage Stage 4 scores tended to be higher than those reported by Rest's (1986) research. The researchers concluded that these findings may indicate that Stage 4 moral orientation may hold more importance for professional accountants and auditors than principled reasoning Stages 5 and 6 due to the profession's rule-oriented nature. Lampe and Finn's research finds results similar to the results of the present study. This is probably because both accountants and college students are immersed in an atmosphere where moral questions and situations are regularly raised.

The results of their study mirror the results of this study. The "P"-scores of both the Italian and American Sports Management students were below the "P"-score of 40, which Rest (1979) records as the average adult score.

Ponemon (1992) studied the influence of accounting firm socialization upon the individual Certified Public Accountants' (CPA'S) level of ethical reasoning. A triangulated research was used to study the selection- 
socialization phenomenon. The participants consisted of a random cross-sectional sample of 180 Certified Public Accountants (CPA'S), a longitudinal sample of 221 auditors in one national firm over a 2-year period, and an experimental study of 23 audit managers' promotion assessments of 54 senior level auditors located in one large practice office. Ethical socialization corroborates the results of all three studies. The study indicates that those progressing to manager and partner positions within the firm tended to possess lower and more homogeneous DIT "P"'-scores. The experimental findings of the research suggested that firm managers' promotion decisions are biased in favor of individuals possessing ethical reasoning that is closer to their own capacity. The results of the study implied that the ethical culture of the accounting firm determines an individual's development to higher levels of ethical reasoning.

Unlike Ponemon (1992), the researcher of this study did not find a statistically significant difference between the moral reasoning of United States lower and upper classmen.

Ponemon and Gabhart (1993) investigated the impact of cross-national differences upon the ethical judgments of individual auditing practitioners. Auditing professionals from two large accounting firms located in the United States and Canada participated in this study. The study found clear evidence of wide differences between Canadian and U.S. accounting professionals with regard to average DIT "P"-scores. The research showed Canadian auditors at all position levels possessed higher and less homogeneous DIT "P"-scores than the U.S. auditors. The results of this study indicate that the process of selection-socialization may not exist in large Canadian firms. The findings of this study highlight the importance of ethical reasoning as a determinant of ethical choice and professional behavior in a wide range of tasks such as the assessment of client competence and integrity, audit materiality, and audit risk.

Unlike Ponemon and Gabhart's (1993), study, the researcher of this study did find that the mean "P"scores of the Italian Sports Management students were slightly higher than the mean "P"-scores of the American Sports Management students, but not significantly so.

Bernardi (1991) investigated the relationship between ethical reasoning and the auditor's ability to detect fraudulent financial statement information. Four hundred ninety four experienced auditors served as participants in the study. An experimental study required the subjects to review a fairly complex and somewhat realistic set of contextual and financial cues regarding the quality of financial statement information from a fictitious client company. Subjects received a cue containing a seeded error that clearly indicated the existence of material error and the real possibility of fraud. The study found that experience, ethical reasoning, and the configuration of experience and ethical reasoning all influenced the individual's ability to detect and frame the questionable accounting entry. The study also found that post-conventional (high DIT) auditors with relatively high levels of domain-specific experience were substantially better in detecting fraud than conventional and pre-conventional (low DIT) auditors. Unlike Bernardi's (1991) research, the researcher of this study did not find a statistically significant difference between the moral reasoning of United States lower and upper classmen.

\section{INSTRUMENTS}

The Defining Issues Test (DIT) developed by James Rest using Kohlberg's six stages of moral judgment was used in this study. The short form of the DIT was used. This form contains three ethical scenarios, each accompanied by a set of questions.

The Defining Issues Test's (DIT's) reliability and validity are well established. Reliabilities in the .70 to .80 range (Cronbach Alpha) have been reported on a considerable number of studies. The short form of the DIT is a survey questionnaire which requires approximately twenty minutes completing and is relatively easy to score. The United States students also received a demographic questionnaire. (See Figure 3.) Internal consistency and test-retest correlations of the DIT are provided by James Rest (1979, p. 239; 1986, p. 101). 


\section{THEORETICAL RATIONALE}

Kohlberg's $(1969,1976,1981)$ theory of moral development combines moral philosophy with cognitive psychology in asserting that cognitive development is a necessary prerequisite for moral reasoning (Selman, 1971: Kuhn, and Kohlberg, 1971). Kohlberg's hypothesis states that individuals move sequentially from stage to stage from lower to higher levels. Individuals with the highest level of moral development use abstract universal principles such as human rights and justice. The highest level of moral maturity is not reached by most individuals. Most individuals function at the lower levels of their peers and legally supported expectations.

The model consists of three levels divided into six stages that must be attained in order to achieve what Kohlberg considers full moral development. Moral development in which behavioral norms are viewed as external to the individual comprises stages one and two. These first two stages are known as the pre-conventional level.

The behavioral rationale for stages one and two is to seek pleasurable consequences. Stage one includes obedience and punishment. A self-centered person defers to power and obeys rules only to avoid punishment. The second stage is made up of an instrumental purpose and exchange orientation. An individual will take others' interests into account only when self beneficial.

Level two, known as the conventional level, includes the third and fourth stages. The third stage is comprised of an interpersonal concordance orientation. Third stage behavior consists of loyalty, affection, and trust. The individual's motivation is to feel like a good person and to be seen so by others as well. The fourth stage stresses law and order. This stage reflects societal expectations as represented in law.

Level three, the post conventional level, includes the final two stages of moral development based on the autonomous or principled level. At this level, people recognize that peer and legally enforceable norms may not fully embody ethical behavior. Conventional norms are followed by individuals when they are consistent with the reflective individual's values and principles. Stage five is made up of social contract orientation. The individual is aware that people hold many conflicting personal views. A fair way of reaching consensus by argument, contract, and due process is sought by the individual at this stage. The individual believes that all values and norms are relative and that apart from democratic consensus all should be tolerated.

Universalizable ethical principles are evaluated in stage six. Right behavior is consistent with universal ethics. Kohlberg's stages of moral judgment are outlined in Figure 1 (also can be found in Elm and Weber, 1994; Trevino and Nelson, 1995; Rest, 1983). This is adapted from Kohlberg (1984) pp 174-176. (See Figure 1.)

The Defining Issues Test (DIT) developed by James Rest adapted Kohlberg's (1984) six stages of moral judgment. The moral dilemmas in the DIT are from the work of Kohlberg (1958) and Lockwood (1970). The DIT determines the level of an individual's moral development. It also seeks the reasons behind the decisions. A series of scenarios is presented to the test-taker. Solutions based on different rationales are offered to the test-taker by the DIT. Individuals may arrive at the same answer, but their reasoning can reflect a substantial difference in moral development and critical thinking levels. The scenarios and responses from the DIT present fundamental, underlying structures of social thought instead of the fine descriptions of specific concepts and ideas. Six moral dilemmas make up the long form of the DIT. A set of forced choice questions is presented for each dilemma. An index measures the relative importance placed on principled moral thinking. The scores indicate the placement of the respondent on a scale analogous to Kohlberg's six stages.

Three ethical scenarios make up the short form of the DIT. A set of questions accompanies each ethical scenario. The test scores are recorded by a Likert-type scale. The subject reads each dilemma and ranks different issues by level of importance. The ranking provides the researcher with the subject's preference for certain modes of thinking on stage structure. The preferences with the higher stages are weighted and averaged. The "P"-score, i.e. the principled score, is calculated from the averages. This score indicates the extent to which a subject reasons in terms of principled ethical stages. The higher the "P"- score, the higher the level of moral reasoning employed by the subject. An index of overall moral judgment development is also present in the DIT, consisting of a composite of all stage scores. Rest deems the first three stages less significant than the latter three. Each of the latter three 
operates with varying importance for different individuals. This can be found in Rest $(1982,1988)$. The test-retest reliabilities for the short form average about .08 lower than those for the full test (The Ninth Mental Measurement Yearbook, p. 304). (See Figure 2.)

\section{RESEARCH QUESTION}

The instrument used in this research consisted of the short form of Rest's Defining Issues Test (DIT). This instrument provided data for the following research question:

1. What is the relationship between Italian Sports Management students' moral reasoning and United States Sports Management students' moral reasoning?

The demographic questionnaire that the United States students received provided data for the following research questions:

2. What is the relationship between gender and the moral reasoning of Sports Management students in the United States?

3. What is the relationship between the moral reasoning of United States lower classmen and upper classmen?

4. What is the relationship between the moral reasoning of United States Catholic and non-Catholic Sports Management students?

\section{STATISTICAL ANALYSIS AND FINDINGS}

a) The Population and Setting

A sample of 41 undergraduate Sports Management students from a private Catholic university in New York City and 31 undergraduate Sports Management students from the University of Rome's Sports Management Program was utilized in this study. Table I describes the sample.

b) Limitations:

The sample size of the United States and Italian Sports Management students is small.

The Italian Sports Management students did not receive a demographic questionnaire.

Table 1 P-scores of United States and Italian Sports Management Students

\begin{tabular}{lllll}
\hline Country & $\mathbf{N}$ & Mean & St. Dev. & SE Mean \\
U.S. & 41 & 22.3 & 12.4 & 1.9 \\
Italy & 31 & 26.4 & 12.35 & 2.22 \\
\hline
\end{tabular}

What is the relationship between Italian Sports Management students' moral reasoning and the United States Sports Management students' moral reasoning?

Principled moral reasoning is measured by "P"- scores for this study. The respondents' mean "P"- scores are depicted in Table 1. As shown in Table 1, the mean "P"- score was 22.3 for the United States Sports Management students with a standard deviation of 12.4. The mean "P"- score was 26.4 for the Italian Sports Management students with a standard deviation of 12.5. Notably, this score falls below the "P"- score of 40 that Rest (1979) records as the average adult score. No definite reason can be given as to why the "P"- scores of this sample fell below the average "P"- scores. Perhaps the result reflects the business environment. Bigel (1998) and Pennino (2001) found similar results in "P"- scores researching businesspersons.

No statistically significant difference was found between Italian and American Sports Management students at the 0.05 level. The Italian Sports Management students' P-scores are slightly higher than the American 
Sports Management students' scores, but not significantly so. No definite reason can be given as to why the "P"scores of the American Sports Management students are lower. We do know that the majority of the American Sports Management students were lower level B.S. students. We also know that the Italian Sports Management students were in a four-year Sports Management Program. However, we do not know whether the Italian Sports Management students were lower or upper B.S. students. There may have been more upper B.S. students than lower B.S. students. According to research, the older the students are, the higher their level of moral reasoning.

Italy is also a highly religious country. Being highly religious might be a factor in moral development, but the higher scores of the Italian Sports Management students were not significant. This might mean that two different cultures can both produce people with adequate moral reasoning.. Flaming, Agacer \& Uddin (2010) found common ground in ethical perceptions across cultures. Beechun, Handy, Westerman, and Hassanbelnaby (2008) found similar results. U.S. subjects and Egyptian subjects had similar results in their self-ratings of intention to behave in the areas of justice, utilitarianism and relativism. However, Ho (2010) found differences can exist in ethical perception when one culture attributes moral significance to something that another culture does not. For example, Burnaz, Atakon, Topen \& Singhapakdi (2009) found overall differences in cultural values shaped ethical decision-making. The study included American, Turkish and Thai marketing professionals. The American business professionals perceived ethics as more important and were more likely to perceive unethical marketing behavior as more serious than the Turkish and Thai marketing professionals. American and Italian cultures may have similar moral values.

Table 2

Descriptive Statistics for United States Sports Management Students - P-scores by Gender

United States: Two Sample T-Test \& CI

\begin{tabular}{llllll} 
& Sample & N & Mean & St. Dev. & SE Mean \\
\hline P-scores & Females & 14 & 23.5 & 10.2 & 2.7 \\
& Males & 27 & 21.7 & 13.6 & 2.6 \\
& Median $=23.33$ & & Maximum $=60.00$ & & \\
\hline
\end{tabular}

What is the relationship between gender and the moral reasoning of Sports Management students in the United States?

Overall, female respondents reported a higher mean "P"- score of 23.5 with a standard deviation of 10.2 than male respondents, who had a mean "P"- score of 21.7 and a standard deviation of 13.6. United States female Sports Management students had mean P-scores which were slightly higher than males, but not significantly so. The descriptive data results are shown in Table 2.

The finding is consistent with research conducted by Pennino (2000), Forte (2001), Bigel (1998), Harris (1990) and Derry (1989). Rest and Derry reported slight differences in the moral reasoning scores of men and women. When differences surfaced, women scored higher than men. Derry stated that if general differences exist between men and women, those differences fade in strong organizational cultures where both men and women are expected to think, evaluate, and act as corporate members (Derry, 1989, p. 857).

According to Harris, women differ only in the self-interest construct. Women as a group don't differ from men in their tolerance/intolerance of fraud, coercion, influence dealing, and deceit (1990, p. 744).

Men were stricter than women when making ethical decisions according to Marques and Azevedo-Pereir's (2009) research. Nguyen, Basuray, Smith, Kopka, \& McCulloh (2008) found that women's advantage in ethical judgment disappeared when taking into consideration the intensity of the moral issue. Biekun, Stedham, Westerman and Yamamura's (2010) study found that women's intentions to behave ethically were also contextually dependent. According to the study, women relied on both justice and utilitarianism when making moral decisions. Men relied only on justice, and their decisions were more universal rather than contextual. Men were more willing than women to mislead competitors in Guidice, Alder and Phelan's (2008) research. Mixed results for the impact of gender on ethical decision -making has been found in the literature. Chang \& Leung (2006); Sweeney \& Costello (2009) and Zgheib 92005) found no difference between the ethical decision-making of males and females. 
Researchers have three different views on the moral development of males and females. Some researchers assert that males and females develop moral reasoning in the same manner. Others contend that males tend toward moral judgments based on the concept of "Justice" while women base their judgments on "Care." A third view holds that emotion, especially empathy, influences moral action more so than the cognitive elements of justice and care.

A single model of development can describe the moral reasoning in males and females according to Kohlberg $(1958,1981)$. The advanced stages in moral reasoning of Kohlberg's model are characterized by a set of abstract moral principles based on justice, equity, and equality. The nature of the problem, not the sex of the participant, will determine whether the care or justice orientation is used.

Boys and girls were notably different in terms of their tendency to use a care or justice perspective in solving moral dilemmas according to Johnston's $(1979,1982,1988)$ study. Both boys and girls in Johnston's study had to select the "best" solution to the problem in several fables. Boys mostly indicated a justice orientation in their moral reasoning. Girls mostly selected a care solution. Gilligan $(1979,1982)$ believes that gender differences exist. Her studies found that men and women approach and solve ethical problems differently.

Daniels, D'Andrea, and Hick's (1995) research dealt with Hawaiian youths. The possible differences in the moral development of male and female youths were researched. The research was conducted by examining 80 children and adolescents of Hawaiian ancestry. Fables were used to study moral development. Their research did not find gender differences in moral reasoning abilities between male and female Hawaiian participants. Daniel, D'Andrea and Hick reported that the care perspective dominated in the responses offered by both male and female students. The research also found that the male participants predominantly responded from a care perspective in all but one of their spontaneous and best solutions. This finding supports Kohlberg's theory but does not support Gilligan's theory.

Gilligan (1982) believes that males and females have different orientations to moral conflict in our society. Gilligan believes that males typically take a justice orientation towards conflicts. They emphasize the importance of rights, justice, and obligations in their process towards resolving conflicts. According to her study, females hold a care orientation which emphasizes the importance of human relations and the welfare and well being of all parties involved. Gilligan emphasizes that while males and females are capable of considering both perspectives, one perspective or orientation usually predominates.

Gilligan and Attanucci (1988) studied real-life dilemmas. The study was entitled "Two Moral Orientations: Gender Differences and Similarities." The participants consisted of 46 men and 34 women. The participants were mostly adolescents and young adults. The research reported that concerns about both justice and care are represented in people's thinking about real-life moral dilemmas. Study participants tended to focus on one set of concerns and minimize the other.

Their research reported an association between moral orientation and gender with men and women using both orientations. The research found that the care-focus dilemmas are most likely to be presented by women and justice-focus dilemmas by men.

Skoe (1994) researched Ethic of Care, Justice, Identity and Gender. Research participants included seventysix females and 58 males from several Boston area high schools and universities, including Harvard University, Boston University, Northeastern University, and University of Massachusetts.

Skoe found that both the care and justice aspects of moral development are related to identity for both men and women. Amongst women, a stronger relationship was found between identity and care than that between identity and justice. No significant gender effect was found in the research. The research speculates that women manifest a higher ethical orientation than men.

Rest's (1979) book entitled “Development in Judging Moral Issues” addresses Gilligan's 1982 charges of sex-bias in Kohlbergian moral judgment. The book reviewed 22 studies assessing sex differences. Only two studies 
had reported a significant difference in "P"- scores between males and females who used the DIT in their research (Chapter 5). Only $6 \%$ of the variance is accounted for by the sex variable in both studies. A more encompassing review and meta analysis in Chapter 4 was provided by Thoma and Rest's (1986) book entitled "Moral Development: Advances in Research and Theory." Thoma and Rest indicated that sex accounts for about one half of a percent of the variance in DIT scores. Education accounts for about 250 times more variance in their analysis. Thoma and Rest's analysis shows that in DIT research, sex differences are rarely significant in junior highs, senior highs, college and graduate students, or adults. The analysis shows that it is not the case that at one age, one gender has an advantage while at another age the other sex has an advantage. The recommendation made by Rest is that whenever sex differences occur, it would be better to check for the influences of other variables, such as IQ, education, or socioeconomic status (SES).

Rest does not believe that gender is a powerful variable. He believes that the attention given to the sex variables in moral judgment research reflect society's current concerns about sex discrimination. According to Rest, the charge of sex bias in moral judgment assessment is based on unsound arguments and ambiguous evidence. This issue is detailed in Rest's 1979 book, Chapter 5, and in his 1986 book, Chapter 4.

The researcher weighted the weaknesses and strengths of both views, keeping in mind that any instrument is potentially biased to some extent.

The DIT, however, appears to be the best instrument available to measure moral reasoning.

Table 3

Descriptive Statistics for the United States Sports Management Students

\begin{tabular}{lllll}
\hline & N & Mean & St. Dev. & SE Mean \\
\hline "P-scores" & 31 & 26.42 & 12.35 & 2.22 \\
& Median $=26.67$ & & Maximum $=50.00$ & \\
\hline
\end{tabular}

We did not have the breakdown between male and female Sports Management students in Italy. The Italian Sports Management students did not receive a demographic questionnaire.

Table 4

Descriptive Statistics for the United States Sports Management Students P-scores by Lower Classmen and Upper Classmen

\begin{tabular}{lccc}
\hline & Lower Classmen & Upper Classmen & Total \\
\hline Females & 11 & 5 & 16 \\
\hline & 11.05 & 4.95 & \\
\hline Males & 0.000 & 0.000 & 26 \\
\hline & 18 & 8 & \\
\hline Total & 17.95 & 8.05 & \\
\hline
\end{tabular}

Chi-Sq $=0.001, \mathrm{DF}=1, \mathrm{P}-$ Value $=0.974 ; 1$ cell with expected counts less than 5

What is the relationship between the moral reasoning of United States lower classmates and upper classmates?

The eleven female lower classmen Sports Management students have a mean "P"-score of 11.05, and the five upper level classmen have a mean "P"-score of 4.95. The 18 male lower level students have a mean "P"-score of 17.95, and the eight upper level classmen have a mean "P"-score of 8.05. According to Rest's (1994) research, increased education is associated with higher levels of moral judgment. The data does not reveal this. Maybe this is because the sample size for lower level classmen is larger than that of the upper level classmen. Also, education levels are differentiated only between freshman, sophomores, juniors and seniors, not between Bachelor's degrees and Master's degrees. No statistically significant differences were found between lower classmen and upper classmen. 
Table 5

Descriptive Statistics for United States Sports Management Students

P-scores of Freshmen, Sophomores, Juniors and Seniors

\begin{tabular}{lccccc}
\hline & Freshmen & Sophomores & Juniors & Seniors & Total \\
\hline Females & 4 & 7 & 6.48 & 3.81 & 0 \\
\hline & 4.57 & 0.042 & 0.372 & 1.14 & \\
\hline Males & 0.071 & 10 & 5 & 1.143 & \\
\hline & 8 & 10.52 & 6.19 & 1.86 & \\
\hline Total & 7.43 & 0.026 & 0.229 & 0.703 & \\
\hline
\end{tabular}

Class status and "P"-scores appear to be independent.

Table 6

Descriptive Statistics for United States Sports Management Students P-scores by Catholic and Other Religions

\begin{tabular}{lccc} 
& P-scores by Catholic and Other Religions & Total & \\
\hline Females & Catholic & Others & 15 \\
\hline & 10 & 5 & \\
\hline Males & 10.50 & 0.50 & 25 \\
\hline & 0.024 & 7 & \\
\hline & 18 & 7.50 & \\
\hline Total & 17.50 & 0.033 & 40 \\
\hline
\end{tabular}

Chi-Sq $=0.127, \mathrm{DF}=1, \mathrm{P}-$ value $0.722 ; 1$ cell with expected counts less than 5

What is the relationship between the moral reasoning of U.S. Catholic and non-Catholic Sports Management students?

The ten female United States Catholic Sports Management students' mean P-score is 10.50, and the five non- Catholic's mean " $P$ "-score is 4.50. The eighteen Catholic male Sports Management students' mean " $P$ "-score is 17.50 , and the seven non-Catholic's mean " $\mathrm{P}$ "-score is 7.50 .

No statistically significant differences were found between Catholic and non-Catholic United States Sports Management students. Perhaps the results reflect that no matter what religion one follows, it is an element in the development of moral reasoning.

A review of the literature from (1978) to 2003 supports the belief that religion supports ethical decisionmaking. However, Kurpis, Bequiri, and Hegelson (2008) found that commitment to moral self-improvement, rather than religiosity, was a better predictor of the importance of ethics, ethical problem recognition, and ethical behavioral intentions. Oumlil \& Baloun (2009) studied U.S and Moroccan managers. They found little or no association with regard to religiosity and ethical intention. Spiritual well-being was related to the philosophical value of idealism in Fernando and Choudhury's (2010) research. According to Ho's (2010) study, religiosity and locus of control are significant values that influence the ethical perception of managers. Intrinsic religiosity plays a role in offsetting the negative impact of extrinsic religiosity on the internalization of moral identity.

\section{RECOMMENDATIONS}

This study should be replicated with a larger sample size of American and Italian Sports Management students with an even distribution of freshman, sophomores, juniors and seniors. Both United States and Italian Sports Management students should receive a demographic questionnaire in order to better understand the importance of professional ethics from a global perspective.

Although this study found no significant correlation between education and the moral reasoning ability of individual students, Rest (1986) and (1992) other research suggest that there is something inherent in the educational process that causes individual thought mechanisms to evolve to higher modes of moral development. Education, 
whether through traditional schooling or training, is a tool that can assist individuals in operating at higher levels of principled moral reasoning.

The result of the study might indicate that differences between males and females are not apparent in strong organizational cultures because men and women are trained to think and judge as organizational members. If this is true, leaders need to examine whether an ethical dilemma or decision would require an individual to have more of a justice or caring orientation in order to solve the problem more ethically. Leaders may need to use a justice orientation when stockholders are involved or when otherwise practical.

An analysis should be conducted of other professionals, organizations and groups, such as doctors, educators, lawyers and accountants.

Additional research across industry types should be conducted to assess what, if any, differences occur in moral reasoning among those industries.

Future research should investigate the relationship between industry types, gender and moral reasoning. It would be beneficial to more fully understand the variations that could affect a leader's moral reasoning.

A sample with more of a variance in education may be drawn to measure a statistical significance between education and "P"- scores.

All college courses, especially business subjects such as accounting, management, finance and marketing should challenge students with ethical dilemmas and situations requiring moral reasoning. Students will be aware of the importance of ethical reasoning in corporate, educational, and institutional settings.

Research has found that ethical education or training had both a positive and neutral impact on ethical decision-making. Awasthi (2008) and Marques \& Azenedo-Pereira (2009) found that taking an ethics course directly affected managerial judgment, but not moral judgment. Also, students who took an ethics course were more inclined to judge an unethical decision as managerially bad compared to other students. According to Cagle \& Baucus (2006) teaching ethics, studying ethical scandals positively impacts students' perceptions of the ethics of business people. Some type of ethical education is recommended for college students.

Educators, especially business educators, must stress that successful leaders have the ability to establish climates of ethicality throughout their organizations. They accomplish this by developing policies and processes that embody principles of respect for all individuals. Students can experience this through role playing.

Corporations or organizations should examine closely their organizational work climate by analyzing the policies, code of ethics and all other processes that embody principles of respect for all individuals of their organizations and firms.

\section{CONCLUSION}

Although no statistically significant difference between Italian and United States Sports Management students was found at the 0.05 level, the Italian students' "P"-Scores were slightly higher than those of the United States students.

The result of this study might be a reflection of the globalization of the world. A country has its own patterns of beliefs, values and practices. Culture defines who they are and how they do things. It embodies the wisdom of those who were part of the culture before. Culture provides and creates a sense of cohesion and solidarity among its people. It also helps maintain continuity and tradition. A country's culture is made up of a set of shared values and beliefs. These values and beliefs affect the perceptions, decisions, and behavior of the people from that country. We all recognize that meaningful differences exist. Today, countries might have different cultures and customs, but due to technology (the Internet and the use of Facebook, Twitter, YouTube, blogs etc.) and the globalization of the economy, people are becoming more and more alike. 
I found the Sports Management students from the University of Rome in Italy to be very similar to our students in the United States. The students from both countries dressed similarly, listened to similar music and found similar activities entertaining.

The researcher of this study would like to thank Professor Anthony Missere, a Sports Management professor at a private Catholic university in New York City, and Dr. Christiana Buscarini, a Sports Management professor at the University of Rome in Italy, for administering the Defining Issues Test (DIT) developed by James Rest to their classes. The researcher would also like to thank Dr. Albert Ovedovitz, a retired professor at a private Catholic university in New York City, for performing the statistical analysis on the data. Their time and consideration given to this study was deeply appreciated.

\section{AUTHOR INFORMATION}

Almerinda Forte is an Associate Professor and Chairperson for the Division of Administration and Economics at St. John's University. She received her Ph.D. from New York University. Dr. Forte has presented papers at several business ethics conferences and international business conferences. She has published several articles in the "Journal of Business Ethics," "International Business and Economics Research Journal," "Journal of Diversity Management." In "Contemporary Issues In Business Ethics (2007)," she published Chapter 4 entitled Business Ethics And The Corporate World. In addition to her teaching experience, she has also had the honor of receiving a Senior Specialist Fulbright and has been appointed a Vincentian Research Fellow. Dr. Forte brings to the classroom her experiences from numerous companies, including Merrill Lynch, Pierce, Fenner and Smith and The New York State Society of CPA's. Dr. Almerinda Forte, Ph.D., Associate Professor and Chairperson, Division of Administration \& Economics, St. John's University, College of Professional Studies, 8000 Utopia Parkway, Queens, N.Y. 11439, USA. E-mail: fortea@stjohns.edu

\section{BIBLIOGRAPHY}

1. Adams, J.S. (1963). Toward an understanding of inequity. Journal of Abnormal and Social Psychology, 67, pp. $422-436$ (a).

2. Adams, J.S. (1965). Inequity in social exchange. In L. Berkowitz (ed.), Advances in Experimental Social Psychology, Vol. 2 (pp. 267-299). New York: Academic Press.

3. Armstrong, M. (1984). Internalization of the Professional Ethic by Certified Public Accountants: A Multidimensional Scaling Approach. Unpublished: University of Southern California, Doctoral Dissertation.

4. Armstrong, M. (1987). Moral development and accounting education. Journal of Accounting Education, $27-43$.

5. $\quad$ Armstrong, R., Williams, R., \& Barrett, J. (2004). The impact of banality, risky shift and escalating commitment on ethical decision making. Journal of Business Ethics, 53, 365-370. doi:10.1023/B:BUSI.0000043491.10007.9a.

6. Awasthi, V. (2008). Managerial decision-making on moral issues and the effects of teaching ethics. Journal of Business Ethics, 78, 207-223. doi: 10.1007/s10551-006-9328-6.

7. Bampton, R., \& Maclagan, P. (2009). Does a 'care orientation' explain gender differences in ethical decision making? A critical analysis and fresh findings. Business Ethics: A European Review, 18(2), 179191. doi: 10. 1111/j.1467-8608.2009.01556.x.

8. Bartels, L., Harrick, E., Martell, K., \& Strickland, D. (1998). The relationship between ethical climate and ethical problems within human resource management. Journal of Business Ethics, 17(7), 799-804. doi: 10.1007/s10551-006-9332-x.

9. Beekun, R., Hamdy, R., Westerman, J., \& Hassab Elnaby, H. (2008). An exploration of ethical decisionmaking processes in the United States and Egypt. Journal of Business Ethics, 82, 587-605. doi: 10.1007/s1055-0079578-y.

10. Beekun, R., Stedham, Y., Westerman, J., \& Yamamura, J. (2010). Effects of justice and utilitarianism on ethical decision making: a cross-cultural examination of gender similarities and differences. Business Ethics: A European Review, 19(4), 309-325. doi: 10. 1111/j.1467-8608.2010.01600.x. 
11. Bernardi, R. (1991). Fraud Detection: An Experiment Testing Differences in Perceived Client Integrity and Competence, Individual Auditor Cognitive Style and Experience, and Accounting Firms. Unpublished doctoral dissertation, Union College.

12. Bierly, P., Kolodinsky, R., \& Charette, B. (2009). Understanding the complex relationship between creativity and ideologies. Journal of Business Ethics, 86, 101-112. doi: 10.1007/s10551-008-9837-6.

13. Bigel, K. (1998). The Ethical Orientation of Financial Planners Engaged In Investment Activities: A Comparison of Practitioners Based on Professionalization and Compensation Sources. Unpublished doctoral dissertation, New York University.

14. Buchan, J. (2005) Ethical decision-making in the public accounting profession: An extension of Ajzen's Theory of Planned Behavior. Journal of Business Ethics, 61, 165-181.doi: 10.1007/s10551-005-0277-2.

15. Burnaz, S., Atakan, M., Topcu, Y., \& Singhapakdi, A. (2009). An exploratory cross-cultural analysis of marketing ethics: The case of Turkish, Thai, and American businesspeople. Journal of Business Ethics, 90, 371-382. doi: 10.1007/s10551-010-0422-4.

16. Buros Institute of Mental Measurements. The Ninth Mental Measurements Yearbook, The University of Nebraska - Lincoln, Lincoln, Nebraska: The University of Nebraska Press.

17. Cagle, J., \& Baucus, M. (2006). Case studies of ethics scandals: Effects on ethical perceptions of finance students. Journal of Business Ethics, 64, 213-229. doi: 10.1007/s10551-005-8503-5.

18. Caldwell, D., \& Moberg, D. (2006). An exploratory investigation of the effects of ethical culture in activating moral imagination. Journal of Business Ethics, 73, 193-204. doi: 10.1007/s10551-006-9190-6.

19. Chan, S.Y.S. \& Leung, P. (2006). The effects of accounting students' ethical reasoning and personal factors on their ethical sensitivity. Managerial Auditing Journal, 21(4), 436-457.

20. Chang, C., \& Yen, S. (2007). The effects of moral development and adverse selection conditions on managers' project continuance decisions: A study in the Pacific-Rim region. Journal of Business Ethics, 76, 347-360. doi: 10.1007/s10551-006-9286-Z..

21. Chavez, G., Wiggins, R., \& Yolas, M. (2001). The impact of membership in the ethics officer association. Journal of Business Ethics, 34, 39-56. doi: 10. 1023/A:1011968010131.

22. Cherry, J., Lee, M., \& Chien, C. (2003). A cross-cultural application of a theoretical model of business ethics: Bridging the gap between theory and data. Journal of Business Ethics, 55, 951-962. doi: 10.1023/A: 1023615520293.

23. Connelly, S., Helton-Fauth, W., \& Mumford, M. (2004). A managerial in-basket study of the impact of trait emotions on ethical choice. Journal of Business Ethics, 51, 245-267. doi:

10.1023/B:BUSI.0000032494.51162.d3.

24. Cullinan, C., Bline, D., Farrar, R., \& Lowe, D. (2008). Organization-harm vs. organization-gain ethical issues: An exploratory examination of the effect of organizational commitment. Journal of Business Ethics, 80, 225-235. doi: 10.1007/s10551-007-9414-4.

25. Curtis, M. (2006). Are audit-related ethical decisions dependent upon mood? Journal of Business Ethics, 68, 191-209. doi: 10.1007/s10551-006-9066-9.

26. Daniels, J., D'Andrea, M., \& Hick, R. (1995). Moral development and Hawaiian youths: Does gender make a difference? Journal of Counseling \& Development 74, 90-93.Derry, R. (1989). An empirical study of moral reasoning among managers. Journal of Business Ethics, 8, pp. 855-862.

27. Derry, R. and R.M. Green. (1989) Ethical Theory in Business Ethics: A Critical Assessment. Journal of Business Ethics, 8,521-533.

28. Elm, D.R. and Weber, J. (1994). Measuring Moral Judgment Interview or the Defining Issues Test? The Netherlands: Kluwer Academic Publishers, Journal of Business Ethics.

29. Ethics Resource Center. (2005, December 31). Federal sentencing guidelines. Retrieved from http://www.ethics.org/resource/federal-sentencing-guidelines

30. Fernando, M. \& Chowdhury, R.M. M. I. (2010). The relationship between spiritual well-being and ethical orientations in decision making. An empirical study with business executives in Australia. Journal of Business Ethics. 95, 211-225. Doi: 10.1007/8/10551-009-0355-4.

31. Fernandes, M.F. (1995). On empirical investigation of the moderating influence of individuals' cognitive moral development on perceptions of inequity and procedural justice (Fairness). Unpublished doctoral dissertation, Washington State University.

32. Flaming, L., Agacer, G., \& Uddin, N. (2010). Ethical decision-making differences between Philippines and United States students. Ethics \& Behavior, 20(1), 65-79, doi: 10.1080/10508420903482624.

2013 The Clute Institute http://www.cluteinstitute.com/ 
33. Flynn, F., \& Wiltermuth, S. (2010). Who's with me? False consensus, brokerage, and ethical decisionmaking organizations. Academy of Management Journal, 53(5), 1074-1089. doi:10.5465/AMJ.2010.54533202.

34. Forte, A. (2001). Business Ethics: A Study of the Moral Reasoning of Selected Business Managers. Unpublished doctoral dissertation, New York University.

35. Fritzsche, D., \& Oz, E. (2007). Personal values' influence on the ethical dimension of decision making. Journal of Business Ethics, 75, 335343. doi: 10.1007/s10551-006-9256-5.

36. Gilligan, C. (1979). Women's place in man's life cycle. Harvard Educational Review, 29, $119-133$.

37. Gilligan, C. (1982). In a different voice: Psychological theory and women's development. Cambridge MA: Harvard University Press.

38. Gilligan, C., \& Attanucci, J. (1988). Two moral orientations: gender differences and similarities. MerrillPalmer Quarterly, 34(3), 223-237.

39. Greenfield, A., Norman, C., \& Wier, B. (2008). The effect of ethical orientation and professional commitment on earnings management behavior. Journal of Business Ethics, 83, 419-434. doi: 10.1007/s10551-007-9629-4.

40. Groves, K., Vance, C., \& Paik, Y. (2007). Linking linear/nonlinear thinking style balance and managerial ethical decision-making. Journal of Business Ethics, 80, 305-325. doi: 10.1007/s10551-007-9422-4.

41. Guidice, R., Alder, G., \& Phelan, S. (2008) Competitive bluffing: An examination of a common practice and its relationship with performance. Journal of Business Ethics, 87, 535-553. doi:10.1007/s10551-0089957-Z.

42. Haines, R., Street, M., \& Haines, D. (2008). The influence of perceived importance of an ethical issue on moral judgment, moral obligation, and moral intent. Journal of Business Ethics, 81, 387-399. doi: 0.1007/s10551-007-9502-5.

43. Harris, J.R. (1990). Ethical values of individuals at different levels in the organizational hierarchy of a single firm. Journal of Business Ethics, 9, 741-750.

44. Hayibor, S., \& Wasieleski, D. (2009). Effects of the use of availability heuristic on ethical decision-making in organizations. Journal of Business Ethics, 84, 151-165. doi: 10.1007/s10551-008-9690-7.

45. Herington, C., \& Weaven, S. (2008). Improving consistency for DIT results using cluster analysis. Journal of Business Ethics, 80,499-514. doi: 10.1007/s10551-007-9451-z.

46. Ho, J. (2010). Ethical perception: Are differences between ethnic groups situation dependent? Business Ethics: A European Review, 19 (2), 154-182. doi: 10.1111/j.1467-8608.2010.01583.x.

47. Hopkins, W., Hopkins, S., \& Mitchell, B. (2008) Ethical consistency in managerial decisions. Ethics \& Behavior, 18(1), 26-43, doi: 10.1080/10508420701519544.

48. Johnston, D.K. (1979). Adolescents' responses to moral dilemmas in fables. Unpublished manuscript, Harvard Graduate School of Education.

49. Johnston, D.K. (1982). Responding to moral dilemmas in fables, ages six to eleven: A brief study of gender differences. Unpublished manuscript, Harvard Graduate School of Education.

50. Johnston, D.K. (1988). Adolescents' solutions to dilemmas in fables: Two moral orientations - two problem-solving strategies In C. Gilligan, J.V. Ward, \& J.M. Taylor (Eds.), Mapping the moral domain (pp. 49-72). Cambridge, MA: Harvard University Press.

51. Karacaer, S., Gohar, R., Aygun, M., \& Sayin, C. (2009). Effects of personal values on auditor's ethical decisions: A comparison of Pakistani and Turkish professional auditors, Journal of Business Ethics, 88, 5364. doi: 10. 1007/s10551-009-0102-4.

52. Kohlberg, L. (1958). The Development of Modes of Moral Thinking and Choice in the Years 10 to 16. Unpublished Doctoral Dissertation, The University of Chicago.

53. Kohlberg, L. (1969). Stage and sequence: the cognitive - developmental approach to socialization. Handbook of Socialization Theory and Research. Goslin D. (ed), Chicago, Rand McNally, pp 347-480.

54. Kohlberg, L. (1976). Moral stages and moralization: the cognitive-developmental approach. Moral Development and Behavior. Lickona, T. (ed). New York: Holt Reinhart, and Winston, pp. 31-55.

55. Kohlberg, L. (1981). The Psychology of Moral Development Volume One. Harper and Row.

56. Kohlberg, L. (1984). The Psychology of Moral Development Volume Two. San Francisco: Harper \& Row Publishers. 
57. Krambia-Kapardis, M., \& Zopiatis, A. (2008). Unchartered territory: Investigating individual business ethics in Cyprus. Business Ethics: A European Review, 17,(2) 138-148.doi: 10.1111/j.14678608.2008.00527.x.

58. Kuhn, D., Langer, J. \& Kohlbeg, L. (1971). Relations Between Logical and Moral Development. Recent Research In Moral Development. Holt: New York, NY.

59. Kurpis, L.,Beqiri, M., \& Helgeson, J.(2008). The effects of commitment to moral self-improvement and religiosity on ethics of business students. Journal of Business Ethics, 80, 447-463. doi: 10.1007/s10551007-9430-4.

60. Lampe, J., \& Finn, D. (1992). A model of auditors' ethical decision process. A Journal of Practice and Theory, Supplement, 1-21.

61. Leitsch, D. (2004). Differences in the perceptions of moral intensity in the moral decision process: An empirical examination of accounting students, Journal of Business Ethics, 53, 313-323. doi: 10.1023/B:BUSI. 0000039378.74446.df.

62. Leitsch, D. (2006). Using dimensions of moral intensity to predict ethical decision-making in accounting. Accounting Education: an international journal, 15(2), 135-149. doi: 10.108/06939280600609151.

63. Leventhal, G. S. (1976a) Fairness in social relationships. In J.W. Thibaut, J. T. Spence, \& R. C. Carson (Eds.), Contemporary topics in social psychology (pp. 211-239). Morristown,NJ: General Learning Press.

64. Leventhal, G.S. (1980). What should be done with equity theory? New approaches to the study of fairness in social relationships. In K.J. Gergen, M.S. Greenberg, and R.H. Willis (eds.) Social Exchange: Advances in Theory and Research (pp. 27-55). New York: Plenum.

65. Lockwood, A.L. (1970). Relations of Political and Moral Thought. Unpublished doctoral dissertation, Harvard University.

66. Loe, T., Ferrell, L., \& Mansfield, P. (2000). A review of empirical studies assessing ethical decisionmaking business. Journal of Business Ethics, 25, 185-204. doi: 10.1023/A:1006083612239.

67. Longenecker, J., Moore, C., Petty, W., Palich, L., \& McKinney, J. (2006). Ethical attitudes in small business and large corporations: Theory and empirical findings from a tracking study spanning three decades. Journal of Small Business Management, 44(2), 167-183. doi: 10. 1111/j.1540627X.2006.00162.x.

68. Marquardt, N., \& Hoeger, R. (2009). The effect of implicit moral attitudes on managerial decision-making: An implicit social cognition approach, Journal of Business Ethics, 85, 157-171. doi: 10.1007/s10551-0089754-8.

69. Marquardt, N. (2010). Implicit mental processes in ethical management behavior. Ethics \& Behavior, 20(2), 128-148. doi: 10.1080/10508421003595950.

70. Marques, P., \& Azevedo-Pereira, J. (2009). Ethical ideology and ethical judgments in the Portuguese accounting profession. Journal of Business Ethics, 86, 227-242. doi: 10.1007/s10551-008-9845-6.

71. Marta, J., Singhapakdi, A., \& Kraft, K. (2008) Personal characteristics underlying ethical decisions in marketing situations: A survey of small business managers. Journal of Small Business Management, 46(4), 589-606. doi: 10.1111/j.1540-627X.2008.00258.x.

72. McCullough, P., \& Faught, S. (2005). Rational moralists and moral rationalists value-based management: Model, criterion and validation. Journal of Business Ethics, 60, 195-205. doi: 10.1007/s10551-004-8317-x.

73. McMahon, J., \& Harvey, R. (2006). An analysis of the factor structure of Jones' moral intensity construct. Journal of Business Ethics, 64, 381-404. doi: 10.1007/s10551-006-0006-5.

74. McMahon, J., \& Harvey, R. (2007). The effect of moral intensity on ethical judgment. Journal of Business Ethics, 72, 335-357. doi: 10.1007/s10551-006-9174-6.

75. Mencl, J., \& May, D. (2009). The effects of proximity and empathy on ethical decision-making: An exploratory investigation. Journal of Business Ethics, 85, 201-226. doi: 10.1007/s10551-008-9765-5.

76. Nguyen, N., Basuray, M., Smith, W., Kopka, D., \& McCulloh, D. (2008). Moral issues and gender differences in ethical judgment using Reidenbach and Robin's (1990) multidimensional ethics scale: Implications in teaching business ethics. Journal of Business Ethics, 77, 417-430. doi: 10.1007/s10551007-9357-9.

77. O'Fallon, M., \& Buttefield, K. (2005). A review of the empirical ethical decision-making literature: 19962003. Journal of Business Ethics, 59, 375-413. doi: 10.1007/s10551-005-2929-7.

78. O'Leary, C., \& Pangemanan, G. (2007). The effects of groupwork on ethical decision-making of accountancy students. Journal of Business Ethics, 75, 215-228. doi: 10.1007/s10551-006-9248-5.

2013 The Clute Institute http://www.cluteinstitute.com/ 
79. Oumlil, B., \& Balloun, J. (2009). Ethical decision-making differences between American and Moroccan managers. Journal of Business Ethics, 84. 457-478. doi: 10.1007/s10551-008-9719-y.

80. Pennino, C. (2000). The Relationship Between Managerial Decision Style, Principled Ethical Reasoning, and Selected Variables in Business Organizations._Unpublished doctoral dissertation, New York University.

81. Ponemon, L. (1992a). Ethical reasoning and selection-socialization in accounting. Accounting, Organizations and Society, 239-258.

82. Ponemon, L., \& Gabhart, D. (1993). Ethical reasoning in accounting and auditing. Vancouver, Canada: Canadian General Accountants' Research Foundation.

83. Premeaux, S. (2004). The link between management behavior and ethical philosophy in the wake of the Enron convictions. Journal of Business Ethics, 85, 13-25. doi: 10.1007/s10551-008-9745-9.

84. Rabl, T., \& Kühmann, T. (2008). Understanding corruption in organizations-development of empirical assessment of an action model. Journal of Business Ethics, 82, 477-495. doi: 10.1007/s10551-008-9898-6.

85. Rest, J.R. (1979).Development In Judging Moral Issues. Minneapolis, Minnesota: University of Minnesota Press.

86. Rest, J.R. (1982). A psychologist looks at the teaching of ethics. Hastings Center Report pp. 29-36.

87. Rest, J.R. (1983). Morality. Handbook of Child Psychology, edited by P. Mussen, $4^{\text {th }}$ Edition, Vol. 3 on Cognitive Development, pp. 556-629. New York, NY: John Wiley and Sons.

88. Rest, J. R. (1986). Moral Development: Advances in Research and Theory. New York: Praeger.

89. Rest, J.R. (1986a). DIT Manual (Third Edition, 8/90 Revision). Minneapolis, MN: Center for the Study of Ethical Development.

90. Rest, J.R. (1988). Why Does College Promote Development In Moral Judgment? Journal of Moral Education, 17 (3), 183-193.

91. Rest, J.R. and Narvaez, D. (1994). Moral development in the professions: Psychology and applied ethics. Hillsdale, N.J. Lawrence Erlbaum Association, Publishers.

92. Ruedy, N., \& Schweitzer, M. (2010). In the moment: The effect of mindfulness on ethical decision making. Journal of Business Ethics, 95, 73-87. doi: 10.1007/s10551-011-0796-y.

93. Schweitzer, M., \& Gibson, D. (2008). Fairness, feelings and ethical decision-making: Consequences of violating community standards of fairness. Journal of Business Ethics, 77, 287-301, doi: 10.1007/s10551007-9350-3.

94. Selman, R. (1971). The importance of reciprocal role-taking for the development of conventional moral thought. Recent Research in Moral Development. Edited by Kohlberg, L. Turiel, E. \& Holt, New York, NY.

95. Shaub, M. (1989). An Empirical Examination of the Determinants of Auditors' Ethical Sensitivity. Unpublished doctoral dissertation, Texas Technological University.

96. Shaub, M. (1994). An analysis of factors affecting the cognitive moral development of auditors and auditing students. Journal of Accounting Education, Spring, 1-24.

97. Sims, R. (2009). Collective versus individualist national cultures: Comparing Taiwan and U.S. employee attitudes toward unethical business practices. Business \& Society, 48, 39-59. doi: $10.1177 / 0007650307299224$.

98. Skoe, E.E., \& Diessner, R. (1994). Ethic of care, justice, identity, and gender: An extension and replication. Merrill-Palmer Quarterly 40 (2), 272-289.

99. Snodgrass, J.E. (1993). Business Ethics: A Comparative Study of Undergraduates (Moral Reasoning). Unpublished doctoral dissertation, University of Idaho.

100. Spicer, A., Dunfee, T., \& Bailey, W. (2004). Does national context matter in ethical decision making? An empirical test of integrative social contracts theory. Academy of Management Journal, 47(4), 610-620.

101. Street, M., \& Street, V. (2006). The effects of escalating commitment on ethical decision-making. Journal of Business Ethics, 64, 343-356. doi: 10.1007/s10551/005-5836-z.

102. Sweeny, B., \& Costello, F. (2009). Moral intensity and ethical decision-making: An empirical examination of undergraduate accounting and business students. Accounting Education: an international journal, 18(1), 75-97. doi: 10-1080/09639280802009454.

103. Trevino, L.K. \& Nelson, K.A. (1995). Managing Business Ethics: Straight Talk About How To Do It Right. New York: John Wiley and Sons. 
104. Valentine, S., \& Rittenburg, T. (2007). The ethical decision-making of men and women executives in international business situations. Journal of Business Ethics, 71, 125-134. doi: 10-1007/s10551-006-9129y.

105. Vitell, S., Bing, M., Davidson, H., Ammeter, A., Garner, B., \& Novicevic, M. (2009) Religiosity and moral identity: The mediating role of self-control. Journal of Business Ethics, 88, 601-613. doi: 10.1007/s10551008-9980-0.

106. Volkema, R., \& Fleury, M. (2002). Alternative Negotiating Conditions and the Choice of Negotiation Tactics: A Cross-cultural Comparison. Journal of Business Ethics, 36, p.381-398.

107. Watson, G., \& Berkley, R. (2008). Testing the value-pragmatics hypothesis in unethical compliance. Journal of Business Ethics, 87, 463-476. doi: 10.1007/s10551-008-9953-3.

108. Watson, G., Berkley, R., \& Papamarcos, S. (2009). Ambiguous allure: The value-pragmatics model of ethical decision making. Business and Society Review. 114(1), 1-29. doi: 10.1111/j.14678594.200900333.x.

109. Westerman, J., Beekun, R., Stedham, Y., \& Yamamura, J. (2007). Peers versus national culture: An analysis of antecedents to ethical decision-making. Journal of Business Ethics, 75, 239-252. doi: $10.1007 / \mathrm{s} 10551-006-9250-\mathrm{y}$.

110. White, D., \& Lean, E. (2008). The impact of perceived leader integrity on subordinates in a work team environment. Journal of Business Ethics, 81, 765-778. doi: 10.1007/s10551-007-9546-6.

111. Zgheib, P.W. (2005). Managerial ethics: An empirical study of business students in the American University of Beirut. Journal of Business Ethics, 61, 69-78. doi: 10.1007/s 10051-004-6394-5.

112. Zhang, J., Chiu, R., \& Wei, L. (2009). Decision-making process of internal whistle blowing behavior in China: Empirical evidence and implications. Journal of Business Ethics, 88, 25-41. doi: 10.1007/s10551008-9831-z.

113. Zhuang, J.,Thomas, S., \& Miller, D. (2005). Examining culture's effect on whistle-blowing and peer reporting. Business \& Society, 44, 462-486.doi: 0.1177/0007650305281848.

Figure 1

Kohlberg's Six Stages of Moral Judgment

\begin{tabular}{|c|c|c|}
\hline Stage and Level & Psychology & Rationale \\
\hline \multicolumn{3}{|l|}{ Level 1: Preconventional } \\
\hline Stage 1: Heteronomous Morality & Egocentric & $\begin{array}{l}\text { Avoids punishment and the superior } \\
\text { authority of others; doesn't consider } \\
\text { interest of others }\end{array}$ \\
\hline $\begin{array}{l}\text { Stage 2: Individualism; Instrumental } \\
\text { Purpose; Individualistic Exchange }\end{array}$ & Concrete & $\begin{array}{l}\text { Follows rules when self-serving; equal } \\
\text { exchange; recognition of other's } \\
\text { interest }\end{array}$ \\
\hline \multicolumn{3}{|l|}{ Level 2: Conventional } \\
\hline Stage 3: Interpersonal Expectations & Caring for others & Puts oneself in other's place \\
\hline $\begin{array}{l}\text { Stage 4: Social System, Conscience } \\
\text { Social System }\end{array}$ & Systematic & See others in terms of social system \\
\hline \multicolumn{3}{|l|}{ Level 3: Postconventional Principled } \\
\hline Stage 5: Social Contract; Utility & Law & $\begin{array}{l}\text { Rational individual who is aware of } \\
\text { rights prior to social/legal contract }\end{array}$ \\
\hline Stage 6: Universal Principles & Morality & $\begin{array}{l}\text { Personal and rational commitment to } \\
\text { universal ethics }\end{array}$ \\
\hline
\end{tabular}


Figure 2

\author{
INSTRUCTION BOOKLET
}

\begin{tabular}{ll}
\hline & DEFINING ISSUES TEST \\
& University of Minnesota \\
Copyright, James Rest & All Rights Reserved, 1979 \\
\end{tabular}

\title{
Opinions about Social Problems
}

The purpose of this questionnaire is to help us understand how people think about social problems. Different people have different opinions about questions of right and wrong. There are no "right" answers to such problems in the way that math problems have right answers. We would like you to tell us what you think about several problem stories.

You will be asked to read a story from this booklet. Then you will be asked to mark your answers on a separate answer sheet. More details about how to do this will follow. But it is important that you fill in your answers on the answer sheet with a \#2 pencil. Please make sure that your mark completely fills the little circle, that the mark is dark, and that any erasures that you make are completely clean.

The Identification Number at the top of the answer sheet may already be filled in when you receive your materials. If not, you will receive special instructions about how to fill in that number.

In this questionnaire you will be asked to read a story and then to place marks on the answer sheet. In order to illustrate how we would like you to do this, consider the following story:

\section{FRANK AND THE CAR}

Frank Jones has been thinking about buying a car. He is married, has two small children and earns an average income. The car he buys will be his family's only car. It will be used mostly to get to work and drive around town, but sometimes for vacation trips also. In trying to decide what car to buy, Frank Jones realized that there were a lot of questions to consider. For instance, should he buy a larger used car or a smaller new car for about the same amount of money? Other questions occur to him.

We note that this is not really a social problem, but it will illustrate our instructions. After you read a story you will then turn to the answer sheet to find the section that corresponds to the story. But in this sample story, we present the questions below (along with some sample answers), Note that all your answers will be marked on the separate answer sheet. 


\section{Figure 2 continued}

First, on the answer sheet for each story you will be asked to indicate your recommendation for what a person should do. If you tend to favor one action or another (even if you are not completely sure), indicate which one. If you do not favor either action, mark the circle by "can't decide."

Second, read each of the items numbered 1 to 12 . Think of the issue that the item is raising. If that issue is important in making a decision, one way or the other, then mark the circle by "great." If that issue is not important or doesn't make sense to you, mark "no," If the issue is relevant but not critical, mark "much," "some," or "little" - depending on how much importance that issue has in your opinion. You may mark several items as "great" or any other level of importance - there is no fixed number of items that must be marked at any one level.

Third, after you have made your marks along the left hand side of each of the 12 items, then at the bottom you will be asked to choose the item that is the most important consideration out of all the items printed there. Pick from among the items provided even if you think that none of the items are of "great" importance. Of the items that are presented there, pick one as the most important (relative to the others), then the second most important, third, and fourth most important.

\section{SAMPLE ITEMS and SAMPLE ANSWERS:}

\begin{tabular}{|c|c|c|c|c|}
\hline$\frac{I}{3}$ & $\sum_{0}$ & $\underline{ }$ & $\stackrel{8}{Z}$ & FRANK AND THE CAR Buy new car $\bigcirc$ Can'r decide $O$ Buy used car \\
\hline (2) & (3) & () & ? & 1. Whether the car dealer was in the same block as where Frank lives. \\
\hline (2) & (3) & (2) & (5) & 2. Would a used car be more economical in the long run than a new car. \\
\hline (2) & (2) & (2) & (5) & 3. Whether the color was green, Frank's favorite color. \\
\hline (2) & (2) & (4) & - & 4. Whether the eubic inch displacement was at least 200 . \\
\hline (2) & (1) & (4) & (5) & 5. Would a large, roomy car be better than a compact car. \\
\hline (2) & (2) & (4) & - & 6. Whether the front connibilies were differential. \\
\hline
\end{tabular}

\begin{tabular}{|c|c|}
\hline Most important item & (3) (1) (3)(1)(3) (2) \\
\hline Second most important & (ㄷ) (1)ல6 \\
\hline Third most important & \\
\hline Fourth most important & (2) \\
\hline
\end{tabular}

Note that in our sample responses, the first item was considered irrelevant; the second item was considered as a critical issue in making a decision; the third item was considered of only moderate importance; the fourth item was not clear to the person responding whether 200 was good or not, so it was marked "no"; the fifth item was also of critical importance; and the sixth item didn't make any sense, so it was marked "no."

Note that the most important item comes from one of the items marked on the far left hand side. In deciding between item $\# 2$ and $\# 5$, a person should reread these items, then put one of them as the most important, and the other item as second, etc. 


\section{Figure 2 continued}

Here is the first story for your consideration. Read the story and then turn to the separate answer sheet to mark your responses. After filling in the four most important items for the story. return to this booklet to read the next story. Please remember to fill in the circle completely, make dark marks, and completely erase all corrections.

\section{HEINZ AND THE DRUG}

In Europe a woman was near death from a special kind of cancer. There was one drug that doctors thought might save her. It was a form of radium that a druggist in the same town had recently discovered. The drug was expensive to make, but the druggist was charging ten times what the drug cost to make. He paid $\$ 200$ for the radium and charged $\$ 2,000$ for a small dose of the drug. The sick woman's husband, Heinz, went to everyone he knew to borrow the money, but he could only get together about $\$ 1,000$, which is half of what it cost. He told the druggist that his wife was dying, and asked him to sell it cheaper or let him pay later. But the druggist said, "No, I discovered the drug and $I^{\prime} \mathrm{m}$ going to make money from it." So Heinz got desperate and began to think about breaking into the man's store to steal the drug for his wife. Should Heinz steal the drug?

\section{ESCAPED PRISONER}

A man had been sentenced to prison for 10 years. After one year, however, he escaped from prison, moved to a new area of the country, and took on the name of Thompson. For eight years he worked hard, and gradually he saved enough money to buy his own business. He was fair to his customers, gave his employees top wages, and gave most of his own profits to charity. Then one day, Mrs. Jones, an old neighbor, recognized him as the man who had escaped from prison eight years before, and whom the police had been looking for. Should Mrs. Jones report Mr. Thompson to the police and have him sent back to prison?

\section{NEWSPAPER}

Fred, a senior in high school, wanted to publish a mimeographed newspaper for students so that he could express many of his opinions. He wanted to speak out against the use of the military in international disputes and to speak out against some of the school's rules, like the rule forbidding boys to wear long hair.

When Fred started his newspaper, he asked his principal for permission. The principal said it would be all right if before every publication Fred would turn in all his articles for the principal's approval. Fred agreed and turned in several articles for approval. The principal approved all of them and Fred published two issues of the paper in the next two weeks.

But the principal had not expected that Fred's newspaper would receive so much attention. Students were so excited by the paper that they began to organize protests against the hair regulation and other school rules. Angry parents objected to Fred's opinions. They phoned the principal telling him that the newspaper was unpatriotic and should not be published. As a result of the rising excitement, the principal ordered Fred to stop publishing. He gave as a reason that Fred's activities were disruptive to the operation of the school. Should the principal stop the newspaper? 
Figure 2 continued

DEFINING ISSUES TEST

University of Minnesota

Copyright, James Rest

All Rights Reserved, 1979

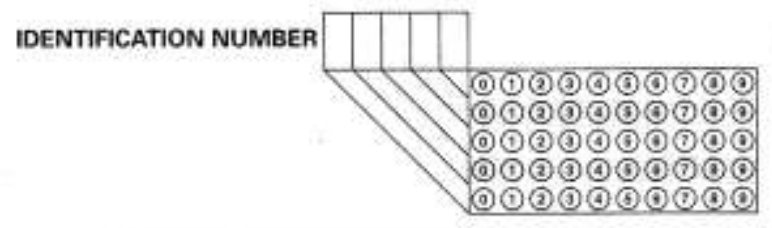

$\frac{5}{5} 55$
00000
00000

HEINZ AND THE DRUG: O Should Steal OCan't Decide OShould not steal

1. Whether a community's laws are going to be upheld.

2. Isn't it only natural for a loving husband to care so much for his wife that he'd steal?

00000 3. Is Heinz willing to risk getting shot as a burglar or going to jail for the chance that stealing the drug might help?

00000 4. Whether Heinz is a professional wrestler, or has considerable influence with professional wrestlers.

00000 5. Whether Heinz is stealing for himself or doing this solely to help someone else.

00000 6. Whether the druggist's rights to his invention have to be respected.

00000 7. Whether the essence of living is more encompassing than the termination of dying, socially and individually,

000008 . What values are going to be the basis for governing how people act towards each other.

9. Whether the druggist is going to be allowed to hide behind a worthless law which only

9. Whether the druggist is going to be allowed to hide behind a worthiess law which only
protects the rich anyhow.

0000010 . Whether the law in this case is getting in the way of the most basic claim of any member of society.

0000011 . Whether the druggist deserves to be robbed for being so greedy and eruel.

00000 12. Would stealing in such a case bring about more total good for the whole society or not.

Most important item (1)(2)(1)(5)(2)(1)(11)(13)

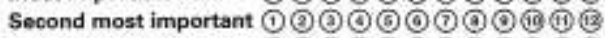

Third most important (1)(3)(1)(3)(1)(11) (13)

Fourth most important (1)(2)(1)(3)(1)(1)(11) (13)

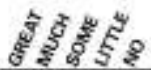

ESCAPED PRISONER: OShould report him OCan't decide O Should not report him

1. Hasn't Mr. Thompson been good enough for such a long time to prove he isn't a bad person?

2. Everytime someone escapes punishment for a crime, doesn't that just encourage more crime?

3. Wouldn't we be better off without prisons and the oppression of our legal system?

4. Has Mr. Thompson really paid his debt to society?

5. Would society be failing what Mr. Thompson should fairly expect?

6. What benefits would prisons be apart from society, especially for a charitable man?

7. How could anyone be so cruel and heartless as to send Mr. Thompson to prison?

8. Would it be fair to all the prisoners who had to serve out their full sentences if Mr. Thompson was let off?

00000

00000 9. Was Mrs. Jones a good friend of Mr. Thompson?

0000010 . Wouldn't it be a citizen's duty to report an escaped criminal, regardless of the circumstances?

0000011 . How would the will of the people and the public good best be served?

00000 12. Would going to prison do any good for Mr. Thompson or protect anybody?

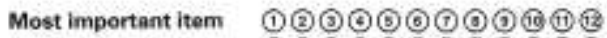

Second most important (1) (3) (3) () (3) (2) (7) (2) (2) (1) (11) (1)

Third most important (1)(3) (3)(6) (3) (6) (3) (6) (2) (1) (1i) (1)

Fourth most important (1) (2) (2) (4) (5) () (7) (1) (1) (1) (1) (13)

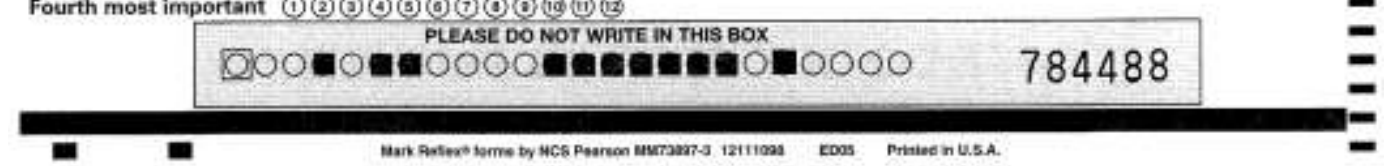


Figure 2 continued

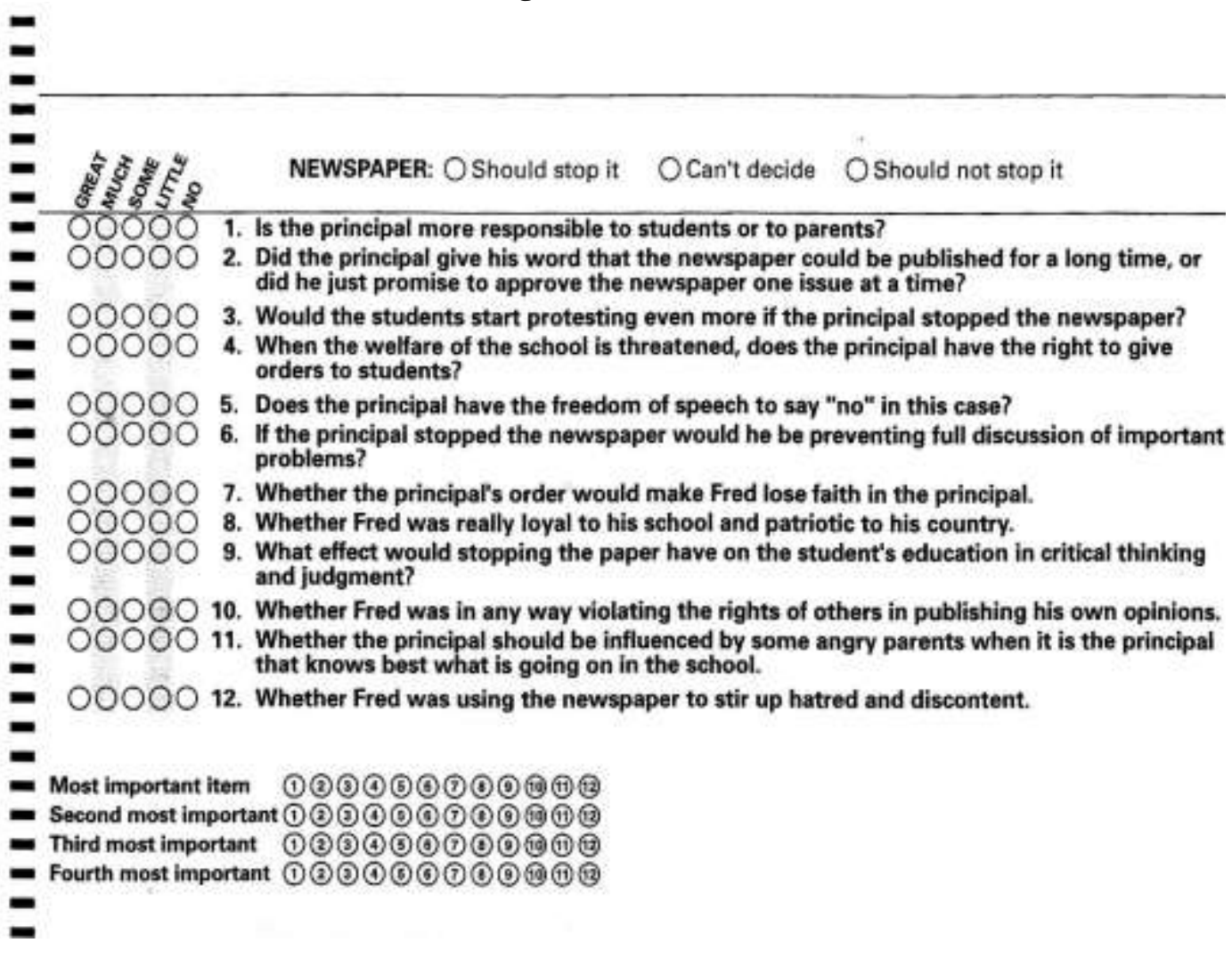

Figure 3

Only the U.S. students received this questionnaire Demographic Questionnaire

Below are questions about your background. For each question, please circle the number next to the answer that best describes your background or fill in the proper response. Please be sure to answer all questions.

1. What is your gender?
a. Male
b. Female

2. Year of Birth

3. Major

4. Are you a
a. Freshman
b. Sophomore
c. Junior
d. Senior

5. Religion
a. Buddhist
b. Greek Orthodox
c. Hindu
d. Islam
e. Jewish
f. Protestant
g. Roman Catholic
h. Russian Orthodox
i. Other 